\title{
MicroRNA, hsa-miR-200c, is an independent prognostic factor in pancreatic cancer and its upregulation inhibits pancreatic cancer invasion but increases cell proliferation
}

\author{
Jun Yu1,2, Kenoki Ohuchida*1,3, Kazuhiro Mizumoto*1,4, Norihiro Sato 1,5, Tadashi Kayashima1', Hayato Fujita1, \\ Kouhei Nakata' and Masao Tanaka'
}

\begin{abstract}
Background: Recently, the microRNA-200 family was reported to affect cancer biology by regulating epithelial to mesenchymal transition (EMT). Especially, the expression of miR-200c has been shown to be associated with upregulating the expression of E-cadherin, a gene known to be involved in pancreatic cancer behavior. However, the significance of miR-200c in pancreatic cancer is unknown.

Methods: In the present study, we investigated the relationship between E-cadherin and miR-200c expression in a panel of 14 pancreatic cancer cell lines and in macro-dissected formalin-fixed paraffin-embedded (FFPE) tissue samples obtained from 99 patients who underwent pancreatectomy for pancreatic cancer. We also investigated the effects of miR-200c on the proliferation and invasion of pancreatic cancer cells.
\end{abstract}

Results: We found that patients with high levels of miR-200c expression had significantly better survival rates than those with low levels of miR-200c expression. We also found a remarkably strong correlation between the levels of miR200c and E-cadherin expression.

Conclusions: These data indicate that miR-200c may play a role in the pancreatic cancer biology and may be a novel marker for the prognosis of pancreatic cancer.

\section{Introduction}

Pancreatic cancer is the fifth leading cause of cancer death and has the lowest survival rate of any solid cancer in the industrialized countries [1,2]. In the past 20 years, 6942 Japanese patients with pancreatic cancer who underwent pancreatectomy showed a very poor prognosis with an overall median survival time (MST) of 11.7 months and a 5-year survival rate of 13.4\% [1]. Extensive molecular analysis of pancreatic cancer has led to discoveries of genetic, epigenetic and, more recently, microRNA alterations [3-6].

\footnotetext{
* Correspondence: kenoki@surg1.med.kyushu-u.ac.jp,

mizumoto@surg1.med.kyushu-u.ac.jp

1 Department of Surgery and Oncology, Graduate School of Medical Sciences, Kyushu University, Fukuoka, Japan

3 Department of Advanced Medical Initiatives, Graduate School of Medical Sciences, Kyushu University, Fukuoka, Japan

Full list of author information is available at the end of the article
}

MicroRNAs (miRNAs) are endogenous, small noncoding RNAs of 14-24 nucleotides that can negatively regulate protein expression at the post-transcriptional level by translational inhibition and/or mRNA degradation, mostly through base pairing with the 3 '-UTR of their target mRNAs [7]. Recently, the abnormal expression of miRNAs was shown to be correlated with cancer. The first evidence suggesting a direct link between miRNAs and human cancer was the localization of $m i R-15 a$ and miR-16-1 within a $30 \mathrm{~kb}$ region of minimal loss on chromosome 13 that is deleted in chronic lymphocytic leukemia (CLL) and that both genes are often deleted or down-regulated in CLL [8]. Other miRNAs, such as miR143 and miR-145 have reduced levels of expression in adenomatous and cancerous stages of colorectal neoplasia [9], while let-7 expression is reduced in lung tumor [10]. The first oncogenic miRNAs (oncomiR-1), the miR- 
17-92 cluster, named from the research on human B cell lymphomas [11], were described as tumor suppressors or oncogenes and brought a novel area of investigation to cancer research $[12,13]$.

Recently, it has been reported that $m i R-200 c$ is a marker of aggressiveness and chemoresistance in female reproductive cancers, that $m i R-200 c$ suppresses invasiveness and restores sensitivity to microtubule-targeting chemotherautic agents in breast and ovrian cancer cells, and that downregulation of $m i R-200 c$ links breast cancer stem cells with normal stem cells [14-16]. Meanwhile, Hurteau et al. revealed that over-expression of $m i R-200 c$ leads to reduced expression of transcription factor 8 (TCF8; also termed ZEB1) and increased expression of $E$ cadherin in breast cancer cells [17,18]. Also, Park et al. reported that $m i R-200 c$ regulates epithelial to mesenchymal transition (EMT) and restores expression of E-cadherin in breast and ovarian cancer cells [18-20]. EMT is a central process in the progression of primary tumors toward metastasis (a switch from the polarized, epithelial phenotype to a highly motile fibroblastoid or mesenchymal phenotype). Furthermore, expression of E-cadherin can predict disease outcome in patients with resectable pancreatic carcinoma, and the therapeutic restoration of E-cadherin was proposed as a strategy to suppress cancer metastasis [21-24].

In the present study, to identify novel relationship between E-cadherin and miR-200c in pancreatic cancer, we quantified $m i R-200 c$ expression in a panel of 14 pancreatic cancer cell lines and in 99 samples of macro-dissected formalin-fixed paraffin-embedded (FFPE) pancreatic tissues. We also investigated the in vitro effects of $m i R-200 c$ upregulation on the proliferation and invasion of pancreatic cancer cells. We found that patients with high levels of $m i R-200 c$ expression had significantly better survival rates compared to those with low levels of $m i R-200 c$ expression. We also found striking correlation between with the levels of $m i R-200 c$ and $E$ cadherin expression. These data suggest that $m i R-200 c$ may be a novel marker for the prognosis of pancreatic cancer.

\section{Materials and methods \\ Cultured cells}

The following 15 pancreatic cancer cell lines were studied: AsPC-1, KP-1N, KP-2, KP-3, PANC-1, BxPC-3 and SUIT-2 (provided by Dr. H. Iguchi, National Shikoku Cancer Center, Matsuyama, Japan); MIA PaCa-2 (Japanese Cancer Resource Bank, Tokyo, Japan); NOR-P1 (established in our laboratory by Dr. Sato); CAPAN-1, CAPAN-2, CFPAC-1, H48N, HS766T and SW1990 (American Type Culture Collection, Manassas, VA, USA). In addition, a human pancreatic ductal epithelial cell line (HPDE, provided by Dr. Ming-Sound Tsao, Uni- versity of Toronto, Toronto, Ontario, Canada) was studied. The cells were maintained as described previously [25].

\section{Pancreatic tissues}

Our study consisted of 99 patients who underwent pancreatic resection for pancreas cancer at the Department of Surgery and Oncology, Kyushu University Hospital (Fukuoka, Japan) from 1992 to 2007. The patients comprised 64 men and 35 women with a median age of 66 years (range, 36-86 years). Survival was measured from the time of pancreatic resection and death was the endpoint. Prognosis was examined in October 2008. The median observation time for overall survival was 15 months and it ranged from 1 to 101 months. Sixty four patients died during follow-up and the other patients were alive and censored.

All resected specimens were fixed in formalin and embedded in paraffin (FFPE) for pathological diagnosis. All tissues adjacent to the specimens were evaluated histologically according to the criteria of the World Health Organization. For all cases, two pathologists were in agreement with regard to pathological features and both confirmed the diagnoses. The stage of tumors was assessed according to the Union Internationale Contre le Cancer (UICC) classification. The clinicopathological characteristics of the tumor collection are described in Table 1. Written informed consent was obtained from all patients, and the study was approved by the Ethics Committee of Kyushu University and conducted according to the Ethical Guidelines for Human Genome/Gene Research enacted by the Japanese Government and the Helsinki Declaration.

\section{miRNA isolation}

miRNAs were extracted from cultured cells using a mirVana $^{\text {TM }}$ miRNA Isolation Kit (Ambion, Austin, TX, USA) and from macro-dissected FFPE pancreatic tissues using an RNeasy FFPE Kit (Qiagen, Tokyo, Japan), following the manufacturer's instructions. Considering the influence of genomic DNA contamination, especially from the FFPE materials, Qiagen provides a special gDNA Eliminator spin column to rapidly remove genomic DNA, and we also performed a DNase digestion step. The extracted RNA was quantified by absorbance at $260 \mathrm{~nm}$ and its purity was evaluated by the absorbance ratio at $260 / 280$ nm with a NanoDrop ND-1000 spectrophotometer (NanoDrop Technologies, Rockland, DE, USA).

\section{Quantitative real-time reverse-transcription polymerase chain reaction ( $q R T-P C R$ )}

The expression of $m i R-200 c$ and RNU6B (U6 snRNA, a reference gene) was measured by qRT-PCR using a TaqMan MicroRNA Reverse Transcription Kit and TaqMan 
Table 1: Clinicopathological Characteristics of 99 Patients with Pancreatic Cancer

\begin{tabular}{|c|c|}
\hline Median age & 65.7 years (range, $36-86$ years) \\
\hline Sex (Male/Female) & $62(62.6 \%) / 37(37.4 \%)$ \\
\hline \multicolumn{2}{|l|}{ Histological diagnosis } \\
\hline Adenocarcinoma & $97(98.0 \%)$ \\
\hline $\begin{array}{l}\text { Adenosquamous } \\
\text { carcinoma }\end{array}$ & $2(2.0 \%)$ \\
\hline \multicolumn{2}{|l|}{ pT category } \\
\hline pT1 & $6(6.1 \%)$ \\
\hline pT2 & $3(3.0 \%)$ \\
\hline рT3 & $57(57.6 \%)$ \\
\hline pT4 & $33(33.3 \%)$ \\
\hline \multicolumn{2}{|l|}{$\mathrm{pN}$ category } \\
\hline pNO & $33(33.3 \%)$ \\
\hline $\mathrm{pN} 1$ & $66(66.7 \%)$ \\
\hline \multicolumn{2}{|l|}{ UICC stage } \\
\hline$|A \&| B$ & $5(5.1 \%) \& 4(4.0 \%)$ \\
\hline$\|A \&\| B$ & $21(21.2 \%) \& 64$ (64.7\%) \\
\hline III & $1(1.0 \%)$ \\
\hline IV & $4(4.0 \%)$ \\
\hline \multicolumn{2}{|l|}{ Histological grade } \\
\hline G1 & $20(20.2 \%)$ \\
\hline $\mathrm{G} 2$ & $43(43.4 \%)$ \\
\hline G3 & $36(36.4 \%)$ \\
\hline \multicolumn{2}{|l|}{ Residual tumor category } \\
\hline Ro & $60(61.2 \%)$ \\
\hline $\mathrm{R} 1$ & $38(38.7 \%)$ \\
\hline \multicolumn{2}{|l|}{ Vessel invasion } \\
\hline Positive & $61(62.2 \%)$ \\
\hline Negative & $37(37.7 \%)$ \\
\hline \multicolumn{2}{|l|}{ Neural invasion } \\
\hline Positive & $84(84.8 \%)$ \\
\hline Negative & $15(15.2 \%)$ \\
\hline
\end{tabular}

Universal PCR Master Mix (No AmpErase ${ }^{\circ}$ UNG; Applied Biosystems, Tokyo, Japan) and a Chromo4 $4^{\mathrm{ma}}$ System (Bio-Rad, Hercules, CA, USA). We followed the manufacturer's protocols to perform two-step real-time RT-PCR for the measurement of miR-200c and RNU6B expression. Each sample was run in triplicate. The level of $m i R-200 c$ expression was calculated from a standard curve constructed with small RNAs from the CAPAN-1 pancreatic cancer cell line. The expression levels of $m i R$ $200 c$ were normalized against the corresponding expression levels of RNU6B.
The levels of E-cadherin mRNA and $18 S$ rRNA were measured by qRT-PCR using a QuantiTect SYBR Green RT-PCR Kit (Qiagen, Tokyo, Japan) and a Chromo4 $4^{\text {tax }}$ System, following the manufacturer's protocols [26]. Each sample was run in triplicate. We designed specific primers for E-cadherin (forward, 5'-tcagcgtgtgtgactgtgaa-3'; reverse, $5^{\prime}$-aggctgtgccttcctacaga- $3^{\prime}$ ), and $18 S$ rRNA (forward, 5'-ctttcgaggccctgtaattg-3'; reverse, 5'-cctccaatggatcctcgtta-3') using Primer 3 software and performed BLAST searches to ensure the specificity of the primers. The PCR products amplified using these primers are small (18S rRNA, 63 bp; E-cadherin, 53 bp), which allowed accurate and sensitive qRT-PCR despite the fragmented RNA extracted from FFPE tissue specimens $[27,28]$. We also included controls without reverse transcriptase to confirm that there was no influence from genomic DNA contamination. The level of E-cadherin mRNA was calculated from a standard curve constructed with total RNA from CAPAN-1 cells and normalized against levels of $18 S$ rRNA. Accuracy and integrity of PCR products were confirmed with an Agilent 1000 Bioanalyzer (Agilent Technologies, Palo Alto, CA, USA).

\section{Cell transfection with miRNA precursors}

Upregulation of miR-200c expression was achieved by transfection with the $h s a-m i R-200 c$ precursor (Pre-miR ${ }^{\mathrm{m}}$ miRNA Precursor; Applied Biosystems). To verify the specificity of the transfection effect, we used a Pre-miR ${ }^{\mathrm{m}}$ miRNA Precursor Negative Control (Applied Biosystems). Transfections were performed by electroporation using a Nucleofector system (Amaxa Biosystems, Köln, Germany) according to the manufacturer's instructions. PANC-1, SUIT-2 and KP-2 cells $\left(1-2 \times 10^{6}\right)$ were transfected with $100 \mathrm{pmol}$ of the indicated precursor or negative control. The degree of mature miR-200c upregulation $48 \mathrm{~h}$ after transfection was verified by quantifying the expression level of mature miR-200c. Cells harvested $48 \mathrm{~h}$ after transfection were also used for cell proliferation or invasion assays.

\section{Propidium iodide (PI) assay}

Cell proliferation was evaluated using a multiwell fluorescence plate reader and a previously described method [29] with modifications [30,31]. Briefly, cancer cells were seeded at $2 \times 10^{4}$ cells/well in Falcon flat-bottom 24-well plates (Becton Dickinson, Franklin Lakes, NJ, USA). 30 $\mu \mathrm{M}$ PI (Wako Ltd., Osaka, Japan) and $600 \mu \mathrm{M}$ digitonin (Wako Ltd.) were then added to each well. After incubation for $90 \mathrm{~min}$ of at $37^{\circ} \mathrm{C}$, the fluorescence intensities of labeled nuclei were measured using a CYTO Fluor ${ }^{\mathrm{rm}}$ II fluorescence multiwell plate reader (PerSeptive Biosystems, Framingham, MA, USA) to determine total cell numbers. 


\section{In vitro Matrigel invasion assay}

Invasion of pancreatic cancer cells was evaluated by the numbers of cells invading Matrigel-coated transwell inserts (Becton Dickinson) as reported previously [25,32]. Briefly, transwell inserts with $8 \mu \mathrm{m}$ pores were coated with Matrigel (20 $\mu \mathrm{g} /$ well; Becton Dickinson). Cancer cells were seeded in the upper chamber at a density of 1.0 $\times 10^{5}$ cells $/ \mathrm{cm}^{2}$ in $250 \mu \mathrm{l}$ of Dulbecco's modified Eagle's medium (DMEM) supplemented with $10 \%$ fetal bovine serum (FBS). After incubation at $37^{\circ} \mathrm{C}$, cells that had invaded to the lower surface of the Matrigel-coated membranes were fixed with $70 \%$ ethanol, stained with hematoxylin and eosin ( $\mathrm{H} \& \mathrm{E})$ and counted in five randomly selected fields under a light microscope.

\section{Statistical analysis}

The in vitrodata are presented as mean values with error bars representing the minimum and maximum or with the standard deviation (SD). The significance level was $p$ $<0.05$. MiR-200c expression in macro-dissected FFPE samples was split into high and low expression groups using a recursive descent partition analysis. Categorical variables were compared with the chi-square test (Fisher's exact probability test). Survival curves were constructed with the Kaplan-Meier product-limit method and compared by log-rank tests. To evaluate independent prognostic factors associated with survival, a multivariate Cox proportional hazards regression analysis was used, with $m i R-200 c$ expression, age, sex pathological tumor (pT) status, pathological node $(\mathrm{pN})$ status, UICC stage, residual tumor $(\mathrm{R})$ status, histological grade $(\mathrm{G})$ and vessel invasion as covariates (Table 2). Statistical significance was defined as $p<0.05$. The statistical analyses in the macro-dissected FFPE samples were performed with JMP 7.01 software (SAS Institute, Cary, NC, USA).

\section{Results}

Quantitative analysis of $m i R-200 c$ expression in pancreatic cancer cell lines

We investigated $m i R-200 c$ expression in 15 pancreatic cancer cell lines and in a non-neoplastic ductal epithelial cell line (HPDE) by quantitative real-time RT-PCR. As shown in Figure 1a, 4 pancreatic cancer cell lines, CAPAN-1, SW1990, CFPAC-1, and H48N, expressed higher levels of $m i R-200 c$ than HPDE. Two pancreatic cancer cell lines, AsPC-1 and CAPAN-2, expressed similar levels of $m i R-200 c$ to HPDE and 9 pancreatic cancer cell lines, BxPC-3, NOR-P1, KP-1N, KP-2, KP-3, Hs766T, SUIT-2, PANC-1 and MIA PaCa-2, expressed lower levels of $m i R-200 c$ than HPDE.

\section{High levels of miR-200c expression correlated with low invasion ability}

Having determined the levels of $m i R-200 c$ expression in the 15 pancreatic cancer cell lines, we investigated the invasion ability of the cell lines that expressed high levels of $m i R-200 c$ (CAPAN-1, CFPAC-1, and H48N) and of the cell lines that expressed low levels of $m i R-200 c$ (KP-3, SUIT-2, and PANC-1) using the Matrigel invasion assay. We seeded $7.5 \times 10^{4}$ cells per Matrigel-coated well and counted the cells that had invaded the Matrigel $50 \mathrm{~h}$ after seeding. As shown in Figure $1 \mathrm{~b}$, all cell lines that expressed high levels of high miR-200c (CAPAN-1, CFPAC-1, and $\mathrm{H} 48 \mathrm{~N}$ ) showed fewer numbers of invading cells compared to the cell lines that expressed low levels of low $m i R-200 c$ (KP-3, SUIT-2, and PANC-1).

Table 2: Univariate and Multivariate Survival Analyses

\begin{tabular}{|c|c|c|c|c|c|c|}
\hline \multirow[b]{2}{*}{ Characteristics } & \multicolumn{3}{|l|}{ Univariate analysis } & \multicolumn{3}{|c|}{ Multivariate analysis } \\
\hline & Hazard Ratio (HR) & 95\% confidence interval & $P$ value & Hazard Ratio (HR) & $95 \%$ confidence interval & $P$ value \\
\hline Age $(<65)$ & 0.9 & $0.5-1.4$ & 0.62 & 0.8 & $0.5-1.4$ & 0.50 \\
\hline Sex(Female) & 0.9 & $0.5-1.5$ & 0.63 & 0.9 & $0.5-1.6$ & 0.69 \\
\hline pT (pT1/2) & 2.2 & $1.4-3.6$ & $<0.001$ & 1.8 & $0.5-5.4$ & 0.35 \\
\hline pN (negative) & 0.4 & $0.2-0.7$ & $<0.001$ & 0.5 & $0.3-1.0$ & 0.06 \\
\hline UICC stage & - & - & 0.003 & - & - & 0.01 \\
\hline Histological grade (G3) & 1.7 & $0.9-2.8$ & 0.07 & 0.8 & $0.6-2.6$ & 0.8 \\
\hline $\begin{array}{l}\text { Residual tumor } \\
\text { (positive) }\end{array}$ & 3.0 & $1.8-5.0$ & $<0.001$ & 3.2 & $1.8-5.8$ & $<0.001$ \\
\hline $\begin{array}{l}\text { Vessel invasion } \\
\text { (positive) }\end{array}$ & 2.3 & $1.4-4.1$ & 0.001 & 1.9 & $1.0-3.6$ & 0.03 \\
\hline Low miR-200c & 1.8 & $1.0-3.5$ & 0.03 & 2.2 & $1.1-4.6$ & 0.02 \\
\hline
\end{tabular}

Relative risk of UICC stage was not shown because of 2 parameters. 


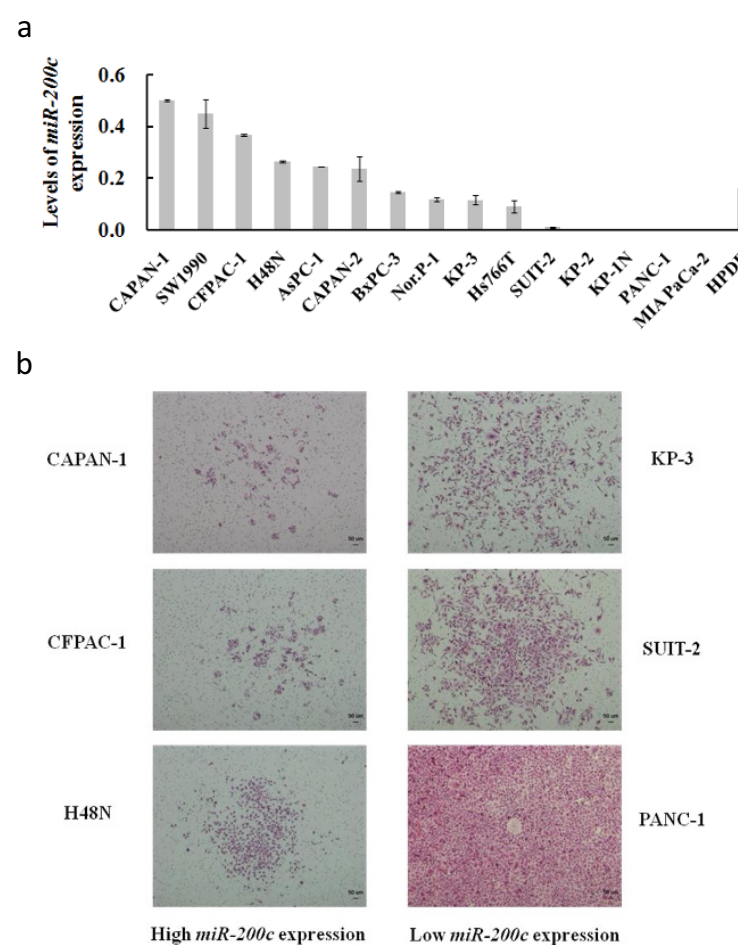

Figure 1 The levels of miR-200c expression in cell lines and the correlation of $m i R-200$ c expression level and the invasion ability of pancreatic cancer cell lines. $a$. The levels of miR-200c expression in 15 pancreatic cancer cell lines and in an HPDE cell line. b. Pictures of invading cells from cell lines expressing high levels of miR-200c (CAPAN1, CFPAC-1 and $\mathrm{H} 48 \mathrm{~N}$ ) and from cell lines expressing low levels of miR200C (KP-3, SUIT-2 and PANC-1). H \& E staining. Original magnification, $10 \times$. Each sample was run in triplicate. Error bars represent SD.

Quantitative analysis of $E$-cadherin mRNA levels in cell lines and significant correlations between $m i R-200 \mathrm{c}$ and $E$ cadherin mRNA levels

We investigated $E$-cadherin mRNA levels by qRT-PCR in the 15 pancreatic cancer cell lines and in the HPDE cell line. Similar to the results of $m i R-200 c$ expression, there were high or low E-cadherin mRNA levels in these cell lines (Figure 2a), and we found there were significant correlations between $m i R-200 c$ and E-cadherin mRNA levels in all cell lines (Pearson's test $p<0.0001$, Figure 2b)

\section{Upregulation of $m i R-200 c$ in pancreatic cancer cell lines}

To upregulate the expression of mature $m i R-200 c$, we transfected the pancreatic cancer cell lines that expressed $m i R-200 c$ at low levels with the $m i R-200 c$ precursor. $24 \mathrm{~h}$ after transfection, we isolated total RNA (including small RNAs) and investigated the levels of $m i R-200 c$ expression. As shown in Figure 3a, SUIT-2 cells transfected with the hsa-miR-200c precursor (precursor group) showed a 38 -fold increase in mature $m i R-200 c$ expression compared with cells transfected with the miRNA Precursor Negative Control (control group). Similar increases of

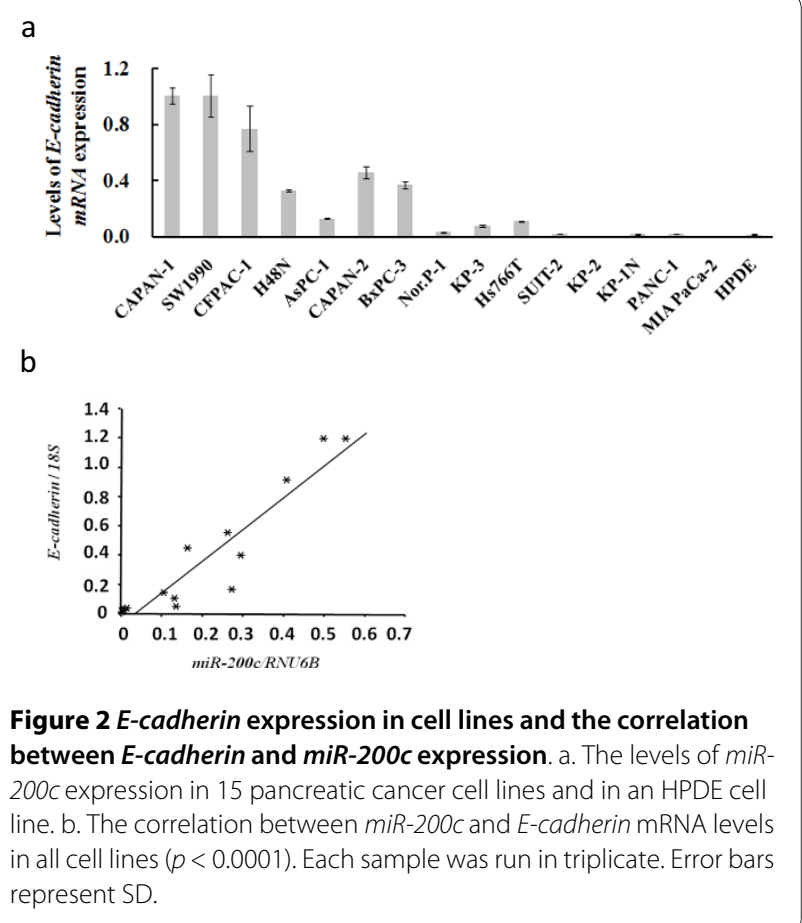

miR-200c expression were seen in KP-3 and PANC-1 cell lines (data not shown).

\section{Upregulation of $m i R$-200c enhanced the levels of $E$-cadherin} mRNA in pancreatic cancer cells

We also investigated the levels of E-cadherin mRNA in the precursor and control groups. As shown in Figure 3b, the SUIT-2 precursor group, which expressed miR-200c at levels 38-fold higher than the control group, showed 3.9-fold higher E-cadherin mRNA levels compared to the control group $24 \mathrm{~h}$ after transfection.

\section{Upregulation of $m i R-200$ c stimulated proliferation in cancer cells}

After confirmation of the upregulation of $m i R-200 c$ in pancreatic cancer cells, we monitored changes in cell proliferation in PANC-1, SUIT-2, and KP-3 cell lines. As shown in Figure $4 \mathrm{a}$, the upregulation of mature $m i R-200 c$ expression in the precursor group enhanced cell proliferation in an upregulation rate-dependent manner for $96 \mathrm{~h}$ after transfection in SUIT-2 cells (upper), and for $120 \mathrm{~h}$ in KP-3 (middle) and PANC-1 cells (bottom).

\section{Upregulation of $\mathbf{m i R}-200 \mathrm{c}$ inhibited invasion of cancer cells}

Next, we investigated the effect of upregulation of mature $m i R-200 c$ expression on the invasive potential of pancreatic cancer cells. Representative microphotographs of cells invading through Matrigel-coated membranes $36 \mathrm{~h}$ after transfection are shown for the control and $m i R-200 c$ precursor cells in the left and right panels of Figure $4 \mathrm{~b}$, respectively. The numbers of invading PANC-1 cells were 
a

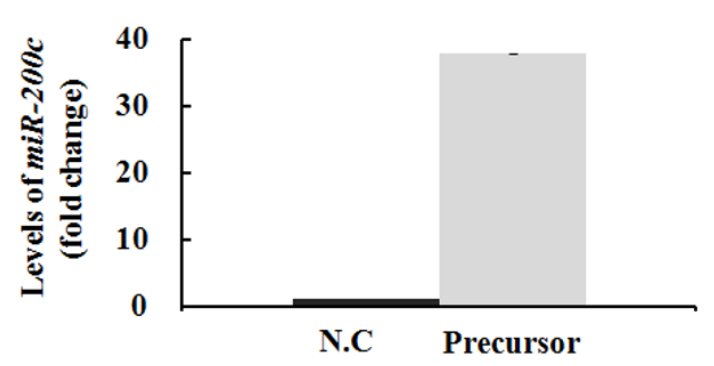

b

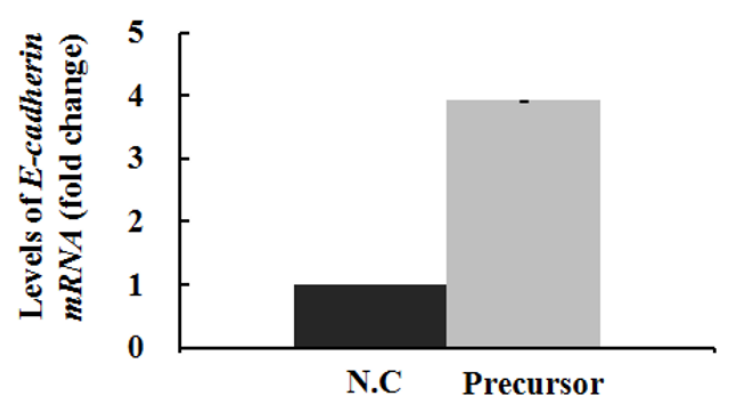

Figure 3 Upregulation of $m i R-200 c$ in pancreatic cancer cell lines and enhanced expression of E-cadherin. a. SUIT-2 cells were transfected with hsa-miR-200c precursor and showed a 38-fold increase in mature miR-200c expression compared with the control $24 \mathrm{~h}$ after transfection. b. Upregulation of miR-200c enhanced expression of $E$ cadherin 3.9-fold relative to the control group. Each sample was run in triplicate. Error bars represent SD.

significantly inhibited in an upregulation rate-dependent manner when cells were transfected with the $m i R-200 c$ precursor $(p<0.001)$, and the number of cells invading in the precursor group was approximately $75 \%$ less than the number of cells invading in the control group (Figure 4c). Similar to the inhibition rate of the PANC-1 precursor group, the KP-3 precursor group also showed a significant inhibition of invasion compared to the control group, with the control group invasion rate inhibited in the precursor group by approximately $75 \%$ (Figure $4 \mathrm{~d}, \mathrm{e}$ ).

\section{Quantitative analysis of miR-200c and E-cadherin mRNA levels in macro-dissected FFPE pancreatic cancer tissues}

We measured miR-200c versus E-cadherin mRNA levels in macro-dissected FFPE samples from 99 patients who underwent pancreatic resection for pancreatic cancer at our institution from 1992 to 2007. The median miR-200c expression level in the macro-dissected pancreatic cancer samples was 0.30 , and the median E-cadherin expression level was 4.41. Similar to the results from cultured cells, we also found that there was a significant correlation between miR-200c and E-cadherin mRNA levels in all macro-dissected pancreatic cancer tissues (Pearson's test $p<0.0001$, Figure 5a).

\section{Univariate and multivariate analyses of $m i R-200 c$ expression for survival time of patients with pancreatic cancer after curative resection}

We classified the patients into two groups of high versus low miR-200c expression (cut-off value: 0.64; the partition was constructed by the overall survival time). The high and low $m i R-200 c$ expression groups were composed of 21 and 78 cases, respectively. In univariate survival analyses based on the Cox proportional hazard model, the miR-200c levels and conventional prognostic factors, such as pT status (pT3 and pT4 versus pT1 and pT2), pN status (pN1 versus pN0), UICC stage (IV, III and IIB versus IIA, and versus IA and IB), tumor grade (G3 versus G1 and G2), R factor (R1 versus R0) and vessel invasion (positive versus negative), were investigated for overall survival (Table 2). We found that $\mathrm{pT}$ status, $\mathrm{pN}$ status, UICC stage, $\mathrm{R}$ factor and vessel invasion were significantly associated with a shorter overall survival $(p<$ $0.001, p<0.001, p=0.002, p<0.001$, and $p=0.001$, respectively). We also found that high $m i R-200 c$ expression was associated with a longer overall survival $(p=$ 0.03 ). The median survival time (MST) and 5-year survival rate were 42 months and $33.5 \%$ in the high $m i R-200 c$ expression group, and 19 months and $11.2 \%$ in the low $m i R-200 c$ expression group, respectively (Figure $5 \mathrm{~b}$ ). In multivariate survival analyses, we found that the overall survival time was significantly dependent on UICC stage $(p=0.01)$, $\mathrm{R}$ factor $(p<0.001)$, vessel invasion $(p=0.03)$ and high $m i R-200 c$ expression $(p=0.02)$.

\section{Discussion}

The present study shows, for the first time, the involvement of $m i R-200 c$ in pancreatic cancer progression and prognosis. We have found that high $m i R-200 c$ expression was related to low invasion ability, and that upregulation of miR-200c expression inhibited cell invasion and stimulated cell proliferation in pancreatic cancer cell lines. We also have found a significant correlation between $m i R$ $200 c$ and E-cadherin expression, and that upregulation of miR-200c expression correlated with increased expression of E-cadherin in pancreatic cancer cell lines. This finding is consistent with previous reports investigating other cancers [14-19]. On the other hand, reduced expression of E-cadherin is regarded as a main molecular event in the dysfunction of the cell-cell adhesion system, triggering cancer invasion and metastasis [33,34]. Recently, Liu et al. revealed that E-cadherin stimulated cell proliferation at intermediate seeding densities, and Mees et al. revealed that metastasis suppressor gene EP300 was regulated by $m i R-200 c$ in ductal adenocarcinomas of the pancreas $[35,36]$. These studies indicate that 


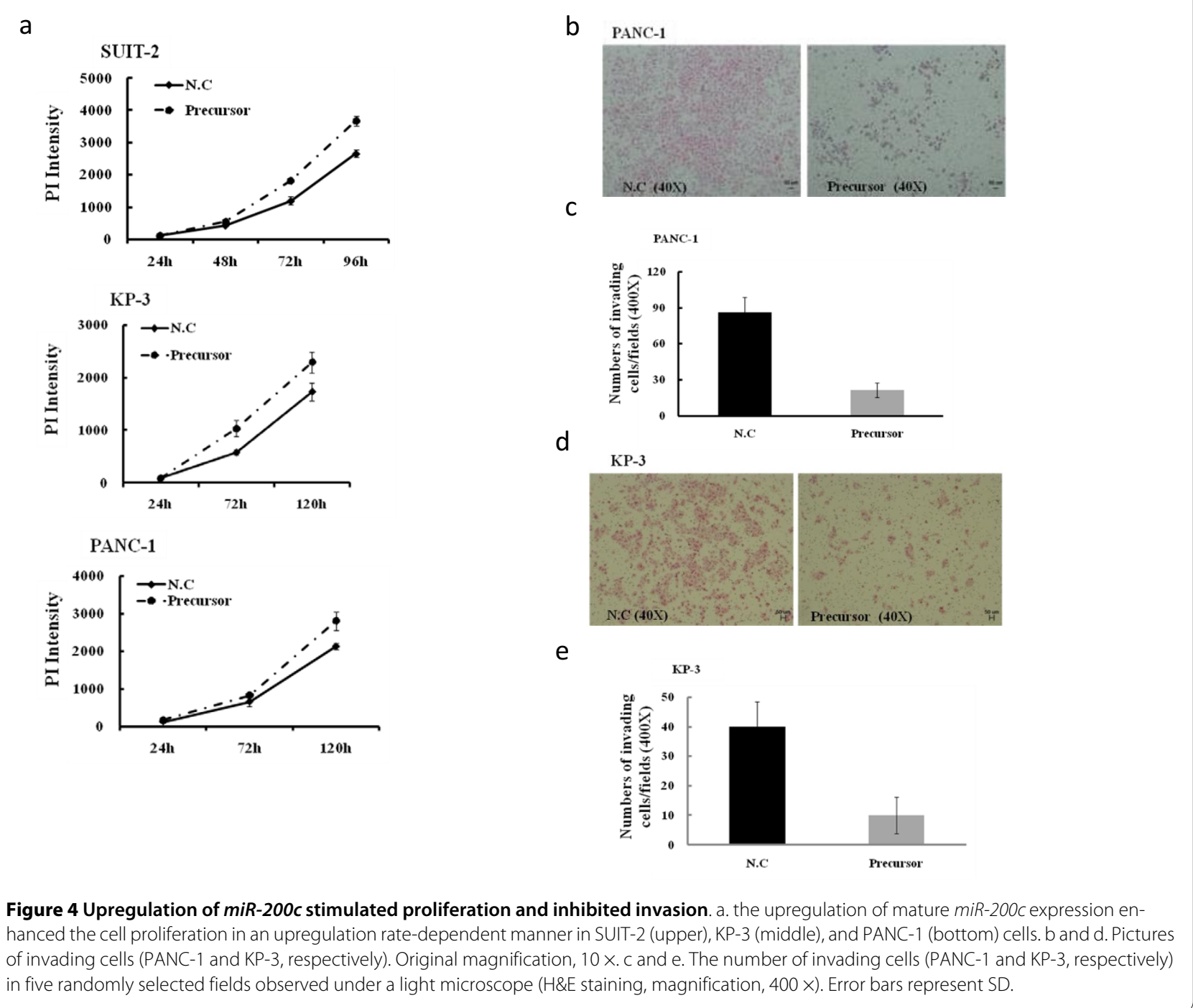

miR-200c plays a key role in the enhancement of proliferation and inhibition of invasion in pancreatic cancer via regulation of E-cadherin. Such inconsistent function is similar to gamma-interferon, which can inhibit tumor growth and enhance metastasis in a TS/A mammary adenocarcinoma model [37].

Furthermore, univariate and multivariate analyses of 99 macro-dissected FFPE pancreatic cancer samples revealed that high $m i R-200 c$ expression was associated with a better prognosis. E-cadherin is considered as a prognosis factor in some cancers [38], and we also found that high E-cadherin expression was associated with a better prognosis in univariate analyses of macro-dissected FFPE pancreatic cancer samples but not in multivariate analyses (data not shown). These findings indicate that E-cadherin can be used as a prognosis factor by immunohistochemistry to detect E-cadherin protein or by qRT-PCR to measure E-cadherin mRNA levels. How- ever, it is difficult to generate a highly specific E-cadherin protein antibody or specific E-cadherin mRNA primers, especially when using fragmented RNA from FFPE samples. miRNAs are small RNAs of 14-24 nucleotides and are more stable than mRNA from FFPE samples [39] and the technologies of miRNA extraction and of qRT-PCR can be controlled more easily than those for mRNAs. Taken together, these findings suggest that $m i R-200 c$ can be a better independent prognosis factor than E-cadherin mRNA in univariate or multivariate analyses, while the latter can be used as a prognosis factor in univariate analyses only. Furthermore, Mitchell, et al. reported that circulating miRNAs are stable blood-based markers for cancer detection [40], suggesting that quantifying the levels of $m i R-200 c$ from patients' pancreatic juice or blood may provide an important marker for indicating the suitability for surgery. 
a

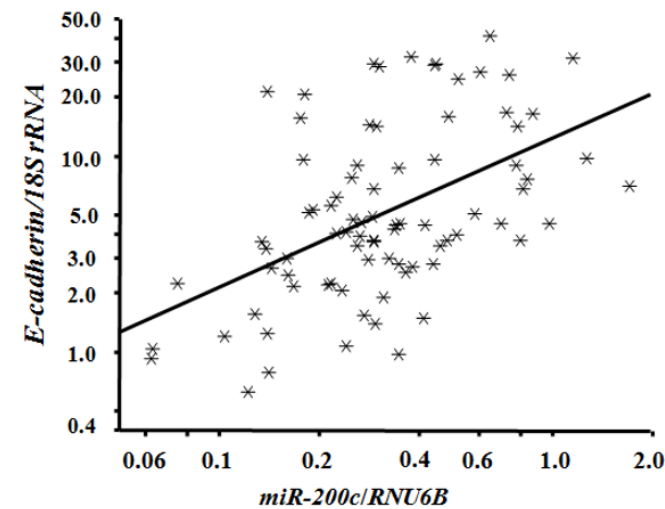

b
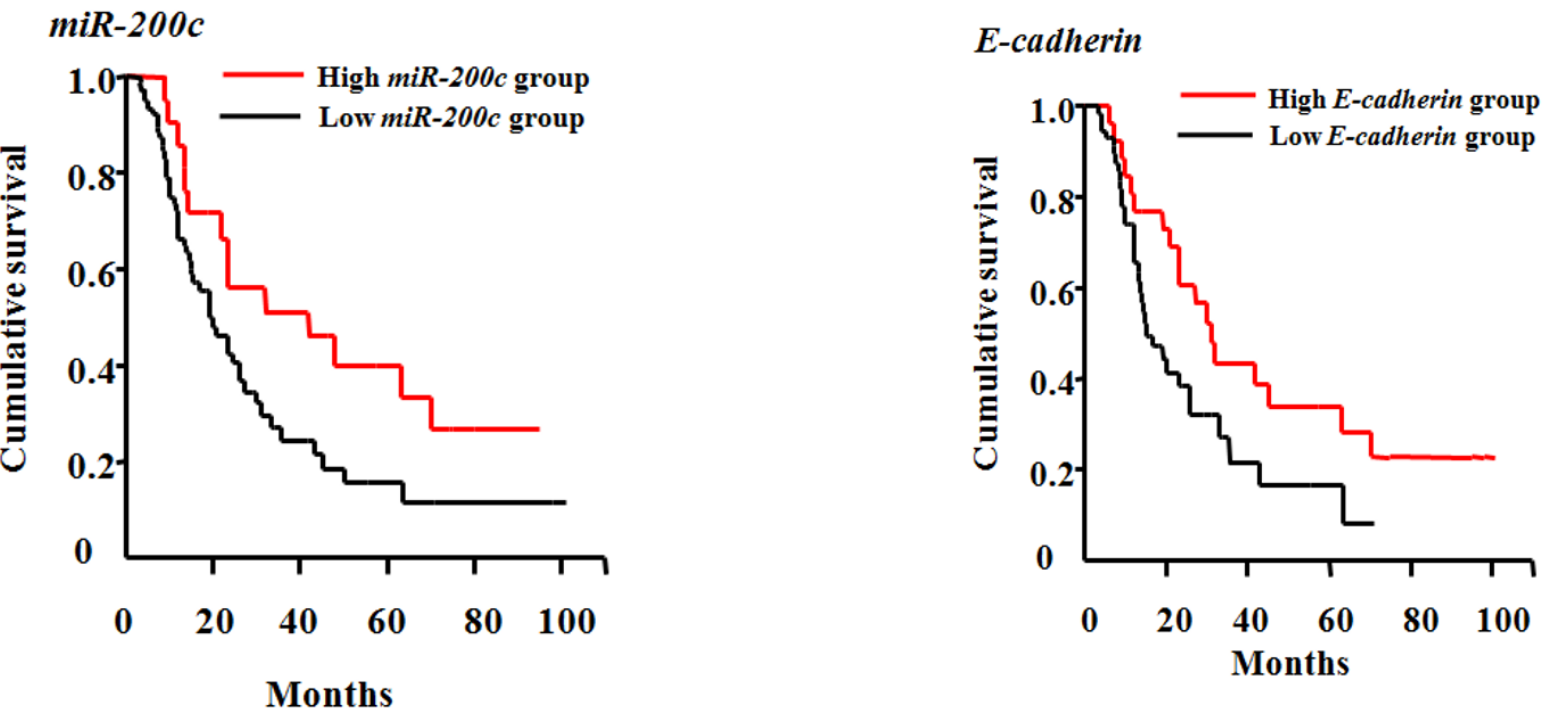

Figure 5 The correlation between miR-200c and E-cadherin expression in macro-dissected FFPE pancreatic cancer tissues. $a$. There was a significant correlation between miR-200c and E-cadherin mRNA levels in all macro-dissected pancreatic cancer tissues (Pearson's test $p<0.0001$ ). b and c. Overall survival time after resection of pancreatic cancer with high miR-200c expression levels versus low miR-200c expression levels and with high E-cadherin mRNA expression levels versus low E-cadherin expression levels. Each sample was run in triplicate.

In conclusion, our results have revealed that high levels of miR-200c expression inhibit cancer invasion and stimulate cancer cell proliferation, possibly via up-regulation of E-cadherin, and that high levels of miR-200c expression correlate with better survival of patients with curative resection of pancreatic cancer. We believe that research into $m i R-200 c$ may bring about new opportunities for the development of drugs and therapeutic strategies for the treatment of pancreatic cancer. On the other hand, the $m i R-200$ family members, like $m i R-200 a / b / c$, $m i R-141$, and $m i R-429$, have similar, but not identical functions $([19,20]$ and $[36])$. We believe that it is necessary to investigate the other family members to complete the picture regarding the $m i R-200$ family and pancreatic cancer.

Competing interests

The authors declare that they have no competing interests.

\section{Authors' contributions}

Conception and design: JY, KO, KM, and MT; analysis and interpretation: JY, TK, and $\mathrm{KN}$; data collection: HF; writing the article: JY; critical revision of the article: KO, KM, NS, and MT; final approval of the article: JY and MT; statistical analysis: $J Y, K O$, and $\mathrm{KN}$; overall responsibility: $\mathrm{KO}$ and $\mathrm{KM}$. All authors read and approved the final manuscript.

\section{Acknowledgements}

We thank Miyuki Ohmori for expert technical assistance in preparing the FFPE sections for macro-dissection and Emiko Manabe and Midori Sato for their help in maintaining the cell line cultures and handling the clinical samples. 


\section{Financial support}

This project was supported by A Grant-in-Aid from the Ministry of Education, Culture, Sports, Science and Technology of Japan, and grants from the Kato Memorial Bioscience Foundation.

\section{Author Details}

'Department of Surgery and Oncology, Graduate School of Medical Sciences, Kyushu University, Fukuoka, Japan, 2Department of Pathology, The Sol Goldman Pancreatic Cancer Research Center, The Johns Hopkins Medical Institutions, Baltimore, MD, USA, ${ }^{3}$ Department of Advanced Medical Initiatives, Graduate School of Medical Sciences, Kyushu University, Fukuoka, Japan, ${ }^{4}$ Kyushu University Hospital Cancer Center, Fukuoka, Japan and ${ }^{5}$ Department of Surgery, Japanese Red Cross Fukuoka Hospital, Fukuoka, Japan

Received: 16 March 2010 Accepted: 28 June 2010

Published: 28 June 2010

\section{References}

1. Matsuno S, Egawa S, Fukuyama S, Motoi F, Sunamura M, Isaji S, Imaizumi T, Okada S, Kato H, Suda K, Nakao A, Hiraoka T, Hosotani R, Takeda K: Pancreatic Cancer Registry in Japan: 20 years of experience. Pancreas 2004, 28:219-30

2. Yamamoto M, Ohashi O, Saitoh Y: Japan Pancreatic Cancer Registry: current status. Pancreas 1998, 16:238-42.

3. Habbe N, Koorstra JB, Mendell JT, Offerhaus GJ, Ryu JK, Feldmann G, Mullendore ME, Goggins MG, Hong SM, Maitra A: MicroRNA miR-155 is a biomarker of early pancreatic neoplasia. Cancer Biol Ther 2009, 8:340-6.

4. Almoguera C, Shibata D, Forrester K, Martin J, Arnheim N, Perucho M: Most human carcinomas of the exocrine pancreas contain mutant c-Kras genes. Cell 1988, 53:549-54.

5. Caldas C, Hahn SA, da Costa LT, Redston MS, Schutte M, Seymour AB, Weinstein $\mathrm{CL}$, Hruban RH, Yeo CJ, Kern SE: Frequent somatic mutations and homozygous deletions of the p16 (MTS1) gene in pancreatic adenocarcinoma. Nat Genet 1994, 8:27-32.

6. Tezel E, Hibi K, Nagasaka T, Nakao A: PGP9.5 as a prognostic factor in pancreatic cancer. Clin Cancer Res 2000, 6:4764-7.

7. Bartel DP: MicroRNAs: genomics, biogenesis, mechanism, and function. Cell 2004, 116:281-97.

8. Calin GA, Dumitru CD, Shimizu M, Bichi R, Zupo S, Noch E, Aldler H, Rattan S, Keating M, Rai K, Rassenti L, Kipps T, Negrini M, Bullrich F, Croce CM: Frequent deletions and down-regulation of micro- RNA genes miR15 and miR16 at 13q14 in chronic lymphocytic leukemia. Proc Nat/ Acad SciUSA 2002, 99:15524-9.

9. Michael MZ, O' Connor SM, van Holst Pellekaan NG, Young GP, James RJ: Reduced accumulation of specific microRNAs in colorectal neoplasia. Mol Cancer Res 2003, 1:882-91.

10. Johnson SM, Grosshans H, Shingara J, Byrom M, Jarvis R, Cheng A, Labourier E, Reinert KL, Brown D, Slack FJ: RAS is regulated by the let-7 microRNA family. Cell 2005, 120:635-47.

11. He L, Thomson JM, Hemann MT, Hernando-Monge E, Mu D, Goodson S, Powers S, Cordon-Cardo C, Lowe SW, Hannon GJ, Hammond SM: A microRNA polycistron as a potential human oncogene. Nature 2005, 435:828-33.

12. Calin GA, Croce CM: Chromosomal rearrangements and microRNAs: a new cancer link with clinical implications. J Clin Invest 2007, 117:2059-66.

13. Wijnhoven BP, Michael MZ, Watson DI: MicroRNAs and cancer. Br J Surg 2007, 94:23-30.

14. Cochrane DR, Howe EN, Spoelstra NS, Richer JK: Loss of miR-200c: A Marker of aggressiveness and chemoresistance in female reproductive cancers. J Oncol 2010, 2010:821717.

15. Cochrane DR, Spoelstra NS, Howe EN, Nordeen SK, Richer JK: MicroRNA$200 \mathrm{c}$ mitigates invasiveness and restores sensitivity to microtubuletargeting chemotherapeutic agents. Mol Cancer Ther 2009, 8:1055-66.

16. Shimono Y, Zabala M, Cho RW, Lobo N, Dalerba P, Qian D, Diehn M, Liu H, Panula SP, Chiao E, Dirbas FM, Somlo G, Pera RA, Lao K, Clarke MF: Downregulation of miRNA-200c links breast cancer stem cells with normal stem cells. Cell 2009, 138:592-603.

17. Hurteau GJ, Carlson JA, Spivack SD, Brock GJ: Overexpression of the microRNA hsa-miR-200c leads to reduced expression of transcription factor 8 and increased expression of E-cadherin. Cancer Res 2007, 67:7972-6.

18. Hurteau GJ, Carlson JA, Roos E, Brock GJ: Stable expression of miR-200c alone is sufficient to regulate TCF8(ZEB1) and restore E-cadherin expression. Cell cycle 2009, 8:2064-9.

19. Park SM, Gaur AB, Lengyel E, Peter ME: The miR-200 family determines the ephthelial phenotype of cancer cells by targeting the E-cadherin repressors ZEB1 and ZEB2. Genes Dev 2008, 22:894-907.

20. Li Y, VandenBoom TG, Kong D, Ali S, Philip PA, Sarkar FH: Up-regulation of miR-200 and let- 7 by natural agents leads to the reversal of epithelialto-mesenchymal transition in gemcitabine-resistant pancreatic cancer cells. Cancer Res 2009, 69:6704-12.

21. Wang F, Sloss C, Zhang X, Lee SW, Cusack JC: Membrane-bound heparinbinding epidermal growth factor like growth factor regulates $\mathrm{E}$ cadherin expression in pancreatic carcinoma cells. Cancer Res 2007, 67:8486-93

22. Howard EW, Camm KD, Wong YC, Wang XH: E-cadherin upregulation as a therapeutic goal in cancer treatment. Mini Rev Med Chem 2008, 8:496-518.

23. Kuniyasu $H$, Ellis $L M$, Evans DB, Abbruzzese JL, Fenoglio CJ, Bucana CD, Cleary KR, Tahara E, Fidler IJ: Relative expression of E-cadherin and type IV collagenase genes predicts disease outcome in patients with resectable pancreatic carcinoma. Clin Cancer Res 1999, 5:25-33.

24. von Burstin J, Eser S, Paul MC, Seidler B, Brandl M, Messer M, von Werder A, Schmidt A, Mages J, Pagel P, Schnieke A, Schmid RM, Schneider G, Saur D: $\mathrm{E}$-cadherin regulates metastasis of pancreatic cancer in vivo and is suppressed by a SNAIL/HDAC1/HDAC2 repressor complex. Gastroenterology 2009, 137:361-71.

25. Ohuchida K, Mizumoto K, Murakami M, Qian LW, Sato N, Nagai E, Matsumoto K, Nakamura T, Tanaka M: Radiation to stromal fibroblasts increases invasiveness of pancreatic cancer cells through tumorstromal interactions. Cancer Res 2004, 64:3215-22.

26. Yu J, Ohuchida K, Nakata K, Mizumoto K, Cui L, Fujita H, Yamaguchi H, Egami T, Kitada H, Tanaka M: LIM only 4 is overexpressed in late stage pancreas cancer. Mol Cancer 2008, 7:93.

27. Abrahamsen HN, Steiniche T, Nexo E, Hamilton-Dutoit SJ, Sorensen BS: Towards quantitative mRNA analysis in paraffin-embedded tissues using real-time reverse transcriptase-polymerase chain reaction: a methodological study on lymph nodes from melanoma patients. $J \mathrm{Mol}$ Diagn 2003, 5:34-41.

28. Godfrey TE, Kim SH, Chavira M, Ruff DW, Warren RS, Gray JW, Jensen RH: Quantitative mRNA expression analysis from formalin-fixed, paraffinembedded tissues using 5 ' nuclease quantitative reverse transcriptionpolymerase chain reaction. J Mol Diagn 2000, 2:84-91.

29. Ohuchida K, Mizumoto K, Ishikawa N, Fujii K, Konomi H, Nagai E, Yamaguchi K, Tsuneyoshi M, Tanaka M: The role of S100A6 in pancreatic cancer development and its clinical implication as a diagnostic marker and therapeutic target. Clin Cancer Res 2005, 11:7785-93.

30. Nieminen AL, Gores GJ, Bond JM, Imberti R, Herman B, Lemasters JJ: A novel cytotoxicity screening assay using a multiwell fluorescence scanner. Toxicol Appl Pharmacol 1992, 115:147-55.

31. Zhang L, Mizumoto K, Sato N, Ogawa T, Kusumoto M, Niiyama H, Tanaka M: Quantitative determination of apoptotic death in cultured human pancreatic cancer cells by propidium iodide and digitonin. Cancer Lett 1999, 142:129-37.

32. Sato N, Maehara N, Mizumoto K, Nagai E, Yasoshima T, Hirata K, Tanaka M: Telomerase activity of cultured human pancreatic carcinoma cell lines correlates with their potential for migration and invasion. Cancer 2001, 91:496-504.

33. Becker KF, Atkinson MJ, Reich U, Becker I, Nekarda H, Siewert JR, Höfler H: $\mathrm{E}$-cadherin gene mutations provide clues to diffuse type gastric carcinomas. Cancer Res 1994, 54:3845-52.

34. Vleminckx K, Vakaet L Jr, Mareel M, Fiers W, van Roy F: Genetic manipulation of E-cadherin expression by epithelial tumor cells reveals an invasion suppressor role. Cell 1991, 66:107-19.

35. Liu WF, Nelson CM, Pirone DM, Chen CS: E-cadherin engagement stimulates proliferation via Rac1. J Cell Biol 2006, 173:431-41.

36. Mees ST, Mardin WA, Wendel C, Baeumer N, Willscher E, Senninger N, Schleicher C, Colombo-Benkmann M, Haier J: EP300-a miRNA-regulated metastasis suppressor gene in ductal adenocarcinomas of the pancreas. Int J Cancer 2010, 126:114-24. 
37. Lollini PL, Bosco MC, Cavallo F, De Giovanni C, Giovarelli M, Landuzzi L, Musiani P, Modesti A, Nicoletti G, Palmieri G: Inhibition of tumor growth and enhancement of metastasis after transfection of the gammainterferon gene. Int J Cancer 1993, 55:320-9.

38. Blechschmidt K, Sassen S, Schmalfeldt B, Schuster T, Höfler H, Becker KF: The E-cadherin repressor Snail is associated with lower overall survival of ovarian cancer patients. Br J Cancer 2008, 98:489-95.

39. Li J, Smyth P, Flavin R, Cahill S, Denning K, Aherne S, Guenther SM, O'Leary $\mathrm{J}$, Sheils O: Comparison of miRNA expression patterns using total RNA extracted from matched samples of formalin-fixed paraffin-embedded (FFPE) cells and snap frozen cells. BMC Biotechnol 2007, 7:36

40. Mitchell PS, Parkin RK, Kroh EM, Fritz BR, Wyman SK, Pogosova-Agadjanyan EL, Peterson A, Noteboom J, O'Briant KC, Allen A, Lin DW, Urban N, Drescher CW, Knudsen BS, Stirewalt DL, Gentleman R, Vessella RL, Nelson PS, Martin DB, Tewari M: Circulating microRNAs as stable blood-based markers for cancer detection. Proc Natl Acad Sci USA 2008, 105:10513-8.

doi: 10.1186/1476-4598-9-169

Cite this article as: Yu et al., MicroRNA, hsa-miR-200c, is an independent prognostic factor in pancreatic cancer and its upregulation inhibits pancreatic cancer invasion but increases cell proliferation Molecular Cancer 2010, 9:169

Submit your next manuscript to BioMed Central and take full advantage of:

- Convenient online submission

- Thorough peer review

- No space constraints or color figure charges

- Immediate publication on acceptance

- Inclusion in PubMed, CAS, Scopus and Google Scholar

- Research which is freely available for redistribution

Submit your manuscript at www.biomedcentral.com/submit
C Biomed Central 